\title{
Assessing of ecological status using geochemical and benthic foraminifera tools (Koper Bay, Northern Adriatic)
}

P. ŽVAB RoŽIČ ${ }^{1}$, J. VIDOVIĆ $^{2}$, V. ĆOSOVIĆ ${ }^{3}$, B. RoŽIČ ${ }^{1}$ AND M. DOLENEC ${ }^{1}$

${ }^{1}$ Department of Geology, Faculty of Natural Sciences and Engineering, Univ. of Ljubljana, Aškerčeva 12, 1000 Ljubljana (*correspondence: petra.zvab@ntf.uni-lj.si) ${ }^{2}$ EuroGeoSurveys, Rue Joseph II 36-38, 1000 Brussels, Belgium

${ }^{3}$ Department of Geology, Faculty of Scienc, Univ. of Zagreb, Horvatovac 102a, 10000 Zagreb, Croatia

Coastal environments are often the subject of different interests with recent anthropogenic pressure coming from industrial and domestic activities. Due to increasing interests about management and protection of such coastal areas the huge effort directed toward developing the tools for the assessment of their environmental and ecological status. Benthic species are preferred because of their characteristics, such as reduced mobility, high diversity and life spans. Within this survey we try to provide the ecological status of Koper Bay (Northern Adriatic) and to determine if benthic foraminiferal assemblages reflect heavy-metal contamination in sediments. For this purpose, sediment samples from the bay were analysed in order to determine the levels of heavy metals in spatial and temporal sections of the bay and to correlate with composition and diversity of foraminiferal assemblages. Mineralogical and geochemical analyses reflect geological features of the hinterland, while trace elements show the differences between coastal and offshore reference location. Benthic foraminiferal assemblages are composed of hyaline Rotalinae forms of moderate to high species diversity, and are dominated by infaunal pollution tolerant Ammonia inflata, Haynesisna sp., Valvulineria bradyana and non-keel Elphidium sp. and subordinately by Ammonia tepida and Haynesina depressula. Stressful environmental conditions were found to influence on benthic foraminiferal occurrence. Statistical analyses on foraminiferal species and trace (heavy) element concentrations reveal possible control of some pollutants $(\mathrm{Fe}, \mathrm{Mn}, \mathrm{Cr}, \mathrm{Cu}, \mathrm{Zr})$ on diversity and some $(\mathrm{Pb}$, $\mathrm{Ni}$ ) on taxonomic composition of foraminiferal assemblages. Multivariate analyses suggested that the terrigenous input (Rižana river flow) make stronger effect on the community than anthropogenic activities monitored through the geochemistry of the sediment. Investigations were supported by the Slovenian Research Agency - research core funding No. P1-0237(C) and P1-0195(B). 